\title{
Informal Networks and Start-Up Entrepreneurs in Spain: Networking Other Entrepreneurs and Angel Investors
}

\author{
Rocío Aliaga-Isla \\ Autonomous University of Barcelona, Barcelona, Spain
}

\begin{abstract}
This paper contributes by containing an examination of the impact of informal networks, such as personally knowing other entrepreneurs and having access to business angel investors, have upon start-up entrepreneurs in Spain. In addition, a pseudo-panel approach is used with micro data from the Spanish Global Entrepreneurship Monitor (GEM) adult population survey over the period 2006-2009. This technique overcomes limitations found when using cross-sectional data. Moreover, this includes a short review of literature using crosssectional data in order to identify how researchers used these data. Results show that informal networks are important for start-up entrepreneurs. Knowing other entrepreneurs personally and having access to angel investors have a positive relationship with start-up entrepreneurs. Also, the findings indicate that startup entrepreneurs in cohorts aged 49-58 and 59-64 do better than younger ones. Furthermore, this article highlights some implications.
\end{abstract}

Keywords: Pseudo-panel, GEM data, start-up entrepreneurs, informal networks

JEL Classification codes: F22, J15, C49, L26

http://dx.doi.org/10.7835/jcc-berj-2014-0100

Entrepreneurs require many kinds of resources to develop their entrepreneurial activities. To find some of these resources, they have to interact with different social networks that include people, institutions, firms, and other entrepreneurs (Greve \& Salaff, 2003). Literature shows that the majority of studies on networks and entrepreneurship have implicitly or explicitly analyzed informal networks and concluded that these kinds of networks are crucial for entrepreneurs. Furthermore, a great quantity of studies focused on the early stages of entrepreneurship (Bosma, Mirjam, \& Thurik, 2004).

For example, researchers have studied the networking activities of entrepreneurs through the three early stage phases of establishing a business. One study showed that the more salient contacts were family members and friends. Also, aspects of running a business were discussed (Greve \& Salaff, 2003). Networks have been seen as a source of resources for entrepreneurs. For instance, information, capital, and intangible resources are accessible for all the members of a network (Coleman, 1988). Moreover, it is well known that informal networks play a role in entrepreneurship because informal networks have not have rules or structure for accessing these resources (Birley, 1985).

Another kind of informal network in which entrepreneurs relied on to engage in entrepreneurial activities is the informal investors such as the business angels (OECD, 2011). Angel investors are usually networks of entrepreneurs or business-people who are recognized as an important source of equity capital at the early stages of entrepreneurship (Maula, Autio, \& Arenius, 2005; Sengupta, 2011). Moreover, business angels 
not only provide financing but managerial experience which increases the likelihood of start-up enterprises surviving. This is because business angels usually have had their own business and/or have been managers of businesses (OECD, 2011).

Then, this study analyzes the impact of informal networks upon start-up entrepreneurs in Spain. To analyze this effect, two constructs have been used as proxies of informal networks: knowing other entrepreneurs personally and having access to business angel investors. The contribution of this study is twofold. First, the study focuses on two crucial proxies informal networks that are highly important for the early stages of entrepreneurship. And, second, it is applied a pseudo-panel approach to analyze the data that has not been applied before to study entrepreneurship. Moreover, this includes a short literature review to examine the use of cross-sectional data. Previous researchers used this approach for studying several topics in the economy (Bernard, Bolduc, \& Yameogo, 2011; Black, Tseng, \& Wilkins, 2010; Heshmati \& Kumbhakar, 1997; Sprietsma, 2012; Warunsiri \& McNown, 2010).

The pseudo panel approach is an alternative technique for estimating the impact of the informal networks upon start-up entrepreneurs in Spain. The pseudo-panel controls for unobserved, individual specific effects avoiding the biased estimations from using cross-sectional surveys. This technique was used using repeated cross-sectional surveys from the Spanish Global Entrepreneurship Monitor (GEM) during the 2006 -2009 period. Therefore, this facilitated to track cohorts by age over time.

The remainder of the paper is organized as follows. Section 2 presents the theoretical framework related to the informal networks and angel investors. Section 3 is devoted to the methodology. This section presents a review of studies that have used cross-sectional data and highlights some limitations. Moreover, it describes the data and the technique used. Section 4 presents the empirical findings. Section 5 presents a discussion and conclusion. Finally, Section 6 highlights some limitations of the study.

\section{Theoretical Framework}

\section{Informal Networks and Entrepreneurship}

Social networks are a fundamental part of social capital theory. Piere Bourdieu (1983) conducted the first analysis of social capital and defined the concept as, "the aggregate of the actual or potential resources which are linked to possession of a durable network of more or less institutionalized relationships of mutual acquaintance or recognition" (p. 248). Individuals tend to create resources through the construction of sociability; therefore, the author highlighted that, "the profits which accrue from membership in a group are the basis of solidarity which make them possible." According to Bourdieu (1983), social capital is decomposable into two elements: the relationship that allows individuals to access resources possessed by their associates and the quality of those resources. Social networks as part of social capital can occur in networks provided by family members, community, organizational relationships, and others (Coleman, 1988). Researchers have argued that social relationships are crucially important for entrepreneurial process because such networks share a variety of resources (Aldrich \& Zimmer, 1986; Johannisson, 1988; Nakhaie, Lin, \& Guan, 2009).

Social capital has been operationalized through the identification of networks and social relationships between individuals. It is well recognized that informal sources of networks are taken into account at the moment of creating a new business. Furthermore, networks have been analyzed regarding the different stages of entrepreneurship. For instance, Birley (1985) has presented a study in which analyzed the informal and formal sources of networks that is used to starting a new firm by entrepreneurs in St. Joseph County in the United States. The results have shown that informal networks such as family, friends, and colleges play an important role contrary to formal networks that appear uniformly inefficient. Other studies have also analyzed the impact of informal networks (Fuller-Love, 2009).

Arent's (1995) study considered three phases of founding a firm: (a) idea development, (b) organizing the founding of a firm, and (c) running a newly established firm. The author supposed that these different stages need different resources and networks that owners used differently. The results revealed that networks are an important resource for establishing a business. In such networks, entrepreneurs can use their relationships for mobilizing complementary resources, getting support and help from the members. People in early stages of entrepreneurship have smaller networks and use less time networking than people in later stages. Similarly, Greve and Salaff (2003) analyzed network activities of entrepreneurs during three phases of establishing a firm: (a) the motivation, (b) planning, and (c) establishing or taking over a firm. The findings showed that 
entrepreneurs built networks that vary in each early phase of entrepreneurship. In addition, people talk with more people during the planning than in other phases, and family networks are presented in all the phases. Although many studies focused on networks as a tangible resource, networks also include intangible resources such as the models of behavior within a network. These patterns are models that could influence the behavior of members of a network, members in a neighborhood, and members in the community, among others (Lafuente, Vaillant, \& Rialp, 2007).

This study contains an examination; at individual level, of the impact of two dimensions of informal networks upon start-up entrepreneurs. First, knowing other entrepreneurs, it means that the entrepreneur knows and networks with other entrepreneurs. In this sense, it should be mentioned that this study is limited to consider that an entrepreneur knows other entrepreneur that could belong to the same social network, neighborhood, or being a simple acquaintance. Secondly, business angel investors are informal credit networks.

In this context, networks are important for leveraging resources from many kinds of networks, for example at school, neighbor associations, churches, peer groups (Falck et al., 2012), and clubs, to mention a few. Thereby, in the field of business, there are networks of successful entrepreneurs in the family, friends, colleagues, and neighbors who are involved in business activities. For example, individuals who create links with entrepreneurial networks will tend to become entrepreneurs and take an advantage of their networks' resources (Davidsson \& Honig, 2003; Klyver, Hindle, \& Meyer, 2008; Mathews \& Moser, 1995; Menzies, Diochon, Gasse, \& Elgie, 2006).

For instance, Klyver et al. (2008) examined the influence of networks on entrepreneurship by comparing the cultures of countries. This study analyzed if this pattern is universal in the process of entrepreneurial networks, using the GEM survey. The empirical results evidenced that entrepreneurial participation is significantly increased by knowing a person who started a business in the past two years. Therefore, this leads to the following hypothesis:

\section{$H_{o}$ 1: Personally knowing other entrepreneurs positively influences start-up entrepreneurs.}

\section{Business Angel Investors and Entrepreneurship}

The concept of business angel investors emerged during the past two decades in the United States and Europe. Business angel investors are informal investors who provide risk capital to new and growing businesses (Maxwell, Jeffrey, \& Lévesque, 2011). Mason (2007) defined business angels as, "high net worth individuals who invest their own money, along with their time and expertise, directly in unquoted companies in which they have no family connection, in the hope of financial gain." Brander, Amit, and Antweiler (2002) explained that, "business angels are typically wealthy individuals who invest their own money in fledgling companies."

The interest in the role of informal investors in the venture capital market has increased since the identification of the business angel's participation in early stages of entrepreneurship (Heukamp, Liechtenstein, \& Wakeling, 2006). Specific literature has pointed out that business angel and other informal venture capitalists' actions reduced the equity gap (Landström, 1995; Reitan \& Sorheim, 2000). It has been identified the importance of their role in entrepreneurship since formal kinds of financing showed red tape and formal procedures that constrained the development of entrepreneurial activities (Parker, 2002). Several studies concluded that informal investors represent the most important source of venture capital for small businesses (Freear, Sohl, \& Wetzel, 1994; Mason \& Harrison, 1995).

Moreover, the literature evidenced that most business angels tend to invest in companies at an early stage (OECD, 2011; Reitan \& Sorheim, 2000). For instance, Moen, Sørheim, and Erikson, (2008) studied born global firms and the role of informal investors. Maula et al. (2005) examined the propensity of individuals to make informal investments in new businesses. They compared the propensity to invest in businesses owned by close family versus more distant businesses. Results of this study supported the idea that business angels tend to invest in businesses owned by others rather than in family businesses.

Among all kinds of informal investors, business angels have become more important than venture capitalists since the primary source of external seed and early stage equity financing in many countries is the angel financing (Mason \& Harrison, 1995). In contrast, venture capitalists tend to invest in established businesses (Maula et al., 2005). Moreover, some studies indicated that angels have invested more in terms of quantity than venture capitalists (Sohl, 2007). Considering that explained above, it is hypothesized that:

$H_{o}$ 2: Business angel investors have a positive relationship with start-up entrepreneurs. 


\section{Methodology}

\section{Drawbacks of Cross-Sectional Data}

The literature reviewed is classified into two groups. First, one group contains papers that have used single year, cross-sectional data from one or two countries. All these papers tried to examine entrepreneurship to understand this phenomenon better around the world. For instance, Ramos-Rodríguez, Medina-Garrido, Lorenzo-Gómez, and Ruiz-Navarro (2010) analyzed the effects of individuals' possession of and access to knowledge on the probability of recognizing good business opportunities in their area of residence. The authors used the GEM data for 2007 from Spain. Moreover, Ramos-Rodríguez, Medina-Garrido, and Ruiz-Navarro (2012) analyzed the influence certain factors have on the likelihood of being hotel and restaurant entrepreneurs. The authors used the GEM data for 2008 from Spain. Köllinger and Minniti (2006) studied the entrepreneurial involvement of black and white Americans. The authors used the GEM data for 2002 from The United States. Roper and Scott (2009) explored the effect that perceptions of financial barriers have during start-up on the start-up decision itself. They used GEM data for 2004 from the United Kingdom.

When individuals embedded themselves in different social networks, they could identify entrepreneurial opportunities differently. Arenius and Clercq (2005) examined two aspects of individuals' embeddedness in networks. They used GEM data for 2005 from Belgium and Finland. In examining this objective, they considered a pooled sample using the country as control variable. Moreover, two models are run for each country. De Clercq and Arenius (2006) examined the effects of an individual's possession of and exposure to knowledge upon engaging in business start-up. They used cross-sectional data from the 2002 GEM for the analysis; these data are from individuals located in Belgium and Finland. Control variable of context is used in a logistic regression for rare events.

The second group of studies used cross-sectional data from several years and countries. For instance, Thompson, Jones-Evans, and Kwong (2009) explored the characteristics of women that operate their businesses from home. This kind of job managing a home-based business can provide the flexibility to deal with family and employment. They used data from the United Kingdom's 2005 and 2006 GEM to conduct this analysis. The authors combined both data sets obtaining 62,173 observations. Moreover, they applied logistic regression and used year of survey as control. Other study examined the impact of the owner-manager's networks upon firm innovation. To do that, data from Iran for 2008 and 2009 and Denmark for 2008, 2009 and 2010 is used by Reza (2012). The data were combined obtaining 12,637 observations. Multiple regressions were applied controlling for country (Appendix).

There is no doubt that all these studies have greatly contributed to understand different topics in different countries around the world. However, the usage of cross-sectional data concerning several countries and survey years should bring errors in estimated variables. As explained in Section 3, this error relates to the unobserved individual heterogeneity and because the samples are collected individually at different times, causing misunderstanding of the results.

\section{Data}

To measure the effects of informal networks upon individuals that conduct a business, data from the Spanish Global Entrepreneurship Monitor's adult population survey for the years 2006 to 2009 are used. Although, GEM cross-sectional survey offers a rich source of information of individuals aged 18 - 64. On the other hand, one of its potential disadvantages is it cannot follow the same individual over time because the data is collected yearly through applying the stratified sampling method (Reynolds et al., 2005).

\section{Variables}

The dependent variable is the nascent entrepreneur; this variable is binary, indicating whether the individual was involved in start-up activities at the time of the survey. This variable is originally binary with $1=$ yes and $0=$ no; however, the methodology section explains this variable's treatment for the pseudo-panel. The explicative variables are personally known other entrepreneurs in the past two years. This variable is binary with $1=$ yes and $0=$ no. And, having access to business angels is another binary variable with values of 1 $=$ yes and $0=$ no; however, both variables have been treated for the pseudo-panel as it is explained in the methodology section. Moreover, some control variables have been used such as for example some demographic 
characteristics such as gender with $1=$ male and $0=$ female and education with $1=$ more than 12 years of education and $0=$ otherwise. The controls also include year survey, cohort age dummies, and autonomous communities. As mentioned before, all these variables have been treated to perform the pseudo panel approach.

Table 1 presents the descriptive statistics of pseudo-panel variables. The average of start-up entrepreneurs is higher in 2007, with 5.7\%, and 2008, with 5.4\%, compared to the averages in the 2006 , with $4.8 \%$, and 2009 , with $1.7 \%$ ). The average of individuals who indicated that they personally knew other entrepreneurs is similar for the years 2006, with $34.8 \%$, and 2007 , with $35.1 \%$; the average is higher for 2008 , with $39.7 \%$, and the lower for 2009 , with $29.9 \%$. The average of individuals that have had access to business angels' networks is higher for 2007, with 3.17\%, and very similar for the other three years with 2006 at 2.7\%, 2008 at 2.8\%, and 2009 at $2.7 \%$. Concerning gender, male start-up entrepreneurs involved in an entrepreneurial activity represent almost 50\% for the three years, excepting 2008 with 50.1\% where they pass the 50\% mark. The average of individuals with more than 12 years of education is similar for the four years; however, the higher average is for 2008 at $44.5 \%$.

Table 1

Descriptive Statistics of Variables

\begin{tabular}{lcccccccccc}
\hline \multirow{2}{*}{ Variables } & \multicolumn{2}{c}{2006} & \multicolumn{2}{c}{2007} & & 2008 & 2009 \\
\cline { 2 - 8 } & Mean & Std. Dev. & Mean & Std. Dev. & Mean & Std. Dev. & Mean & Std. Dev. \\
\cline { 2 - 8 } Start-up entrepreneurs & 0.048 & 0.013 & 0.057 & 0.012 & 0.054 & 0.006 & 0.017 & 0.008 \\
Personally know other entrepreneurs & 0.348 & 0.081 & 0.351 & 0.076 & 0.397 & 0.030 & 0.299 & 0.075 \\
Access business angels & 0.027 & 0.004 & 0.031 & 0.001 & 0.028 & 0.002 & 0.027 & 0.003 \\
Male & 0.492 & 0.025 & 0.497 & 0.033 & 0.501 & 0.015 & 0.494 & 0.026 \\
More than 12 years of education & 0.434 & 0.135 & 0.412 & 0.112 & 0.445 & 0.117 & 0.426 & 0.098 \\
N & \multicolumn{2}{c}{28082} & & 27622 & & 30572 &
\end{tabular}

\section{Econometric Model: The Pseudo Panel}

Although GEM cross-section surveys offer a rich source of information about individuals, one of its potential disadvantages is that it cannot follow the same individual over time because the researchers collect data yearly. To overcome this limitation, this research includes a constructed pseudo-panel of cohorts by age of individuals with a fixed membership over time. Following this approach, it becomes possible to track cohorts over time as units of the observations. Moreover, economists have used the pseudo-panel approach to study a variety of issues such as education, employment, and electricity demand, to mention a few (Black et al., 2010; Bernard et al., 2011; Warunsiri \& McNown, 2010).

Table 2

Number of Observations by Cohort

\begin{tabular}{|c|c|c|c|c|c|c|}
\hline \multirow{2}{*}{ Year survey } & \multicolumn{6}{|c|}{ Cohort by age } \\
\hline & Age $<29$ & Age $>28$ & Age $>38$ & Age $>48$ & Age $>58$ & Total \\
\hline 2007 & 5,398 & 6,591 & 7,381 & 6,003 & 2,507 & 27,880 \\
\hline 2009 & 5,434 & 6,716 & 8,269 & 6,425 & 2,044 & 28,888 \\
\hline Total & 22,746 & 27,193 & 31,523 & 24,756 & 9,735 & 115,953 \\
\hline
\end{tabular}


Table 2 shows the five cohorts by age for Spanish pre-start-up entrepreneurs with a span of 10 years each. In every case, the cell size exceeds 100 individuals, which is sufficient to minimize biases in a pseudo panelestimation (Dargay, 2007). Indeed, most authors ignore measurement errors in empirical applications when the cohort size is sufficiently large. If there are large enough cohorts or large enough samples, then the repeated surveys over time will generate a time series that researchers can use to infer behavioral relationships for the cohort as a whole (Deaton, 1985).

Constructing the pseudo-panel, there is Equation 1 with a set of yearly cross-sections, as $T$, about individuals, using $i$, that belong to a specific time period of $\mu_{i}$ sing individual-specific, time-constant, unobserved heterogeneity and unobserved idiosyncratic error $v_{i t}$ that varies between individuals and over time (Baltagi, 2005).

$y_{i t}=\chi_{i t}^{\prime} \beta+\mu_{i}+v_{i t} \quad \mathrm{t}=1, \ldots, \mathrm{T}$

As, researchers know, it is impossible to include the ability variable that remains on the $\mu_{i}$ individual-specific time-constant. With this, one cannot control the heterogeneity when estimating Equation 1 with individual survey data, so the least squared estimates will be biased and inconsistent. To overcome such limitations, Deaton (1985) defined a set of C ( $c=a, \ldots, C)$ cohorts based on year-of-birth. Thereby, an average of cohort members will help to obtain an equation expressed in terms of cohort means in Equation 2. These cohorts become units of observation in the pseudo-panel. Then, averaging Equation 1 over the cohort members eliminates the individual heterogeneity such as the abilities across individuals.

$$
\overline{y_{c t}}=\overline{\chi_{c t}^{\prime}} \beta+\overline{\mu_{c t}}+\overline{v_{c t}} \quad \mathrm{t}=1, \ldots, \mathrm{T}
$$

Deaton (1985) defined $\overline{\mu_{c t}}$ as the, "average of fixed effects," for those individuals belonging to cohort $c$ in year $t$ is not, "constant over time," because data comes from surveys of different years (p. 116). Consequently, it is very likely that $\overline{\mu_{c t}}$ will correlate with $\overline{\chi_{i t}}$ causing inconsistent estimates. Nonetheless, if the sample size in each cohort is sufficiently large, one can treat $\overline{\mu_{c t}}$ as the true cohort effect $\left(\mu_{i}\right)$. In this case, $\overline{\mu_{c t}} \approx \mu_{c}$ allowing one to estimate Equation 3:

$$
\overline{y_{c t}}=\overline{\chi_{c t}^{\prime}} \beta+\mu_{c}+\overline{v_{c t}} \quad \mathrm{t}=1, \ldots, \mathrm{T}
$$

Furthermore, since the number of observations vary substantially, the disturbance term $\overline{v_{i t}}$ is heteroskedastic, triggering biased standard errors. Therefore, the heteroscedasticity is corrected using weighted least squared (WLS) estimations by weighting each cell with the squared root of the number of observations in each cell (Dargay, 2007). Moreover, as the concern is with a discrete choice that an individual who is involved in entrepreneurship makes at time $t$, the averaging of a binary dependent variable leads to interpreting the proportion of individuals that are involved in entrepreneurial activities in the cohort $c$ at time $t$.

\section{Empirical Findings}

Table 3 presents estimates from the pseudo-panel with data from the early stage of entrepreneurship. The focus of Model 1 is on control variables, and the focus of Model 2 is on explicative variables. The results showed an increase in the $R^{2}$, suggesting that the proportion of variance in the dependent variables is better explained in Model 2. 
Table 3

Pseudo-Panel for Start-up Entrepreneurs

\begin{tabular}{|c|c|c|}
\hline \multirow{2}{*}{ Variables } & \multicolumn{2}{|c|}{ Start-up entrepreneurs } \\
\hline & Model (1) & Model (2) \\
\hline \multicolumn{3}{|l|}{ Explicative variables } \\
\hline \multirow[t]{2}{*}{ Knowing other entrepreneurs } & & $0.0186^{* * *}$ \\
\hline & & $(0.00125)$ \\
\hline \multirow[t]{2}{*}{ Access to informal credit networks (business angels) } & & $0.715^{* * *}$ \\
\hline & & $(0.0236)$ \\
\hline \multicolumn{3}{|l|}{ Controlling for } \\
\hline \multirow[t]{2}{*}{ Male } & $0.167 * * *$ & $0.152 * * *$ \\
\hline & $(0.00390)$ & $(0.00425)$ \\
\hline \multirow[t]{2}{*}{ More than 12 years of education } & $0.0204 * * *$ & $0.0280 * * *$ \\
\hline & $(0.00125)$ & $(0.00148)$ \\
\hline \multirow[t]{2}{*}{ Being immigrant } & $0.738 * * *$ & $0.764 * * *$ \\
\hline & $(0.0125)$ & $(0.0178)$ \\
\hline \multicolumn{3}{|l|}{${ }^{1}$ Autonomous communities } \\
\hline \multirow[t]{2}{*}{ Madrid } & $-5.48 \mathrm{e}-05 * * *$ & $-5.89 \mathrm{e}-05^{* * *}$ \\
\hline & $(2.85 \mathrm{e}-06)$ & $(1.55 \mathrm{e}-06)$ \\
\hline \multirow[t]{2}{*}{ Navarra } & $-0.000146^{* * *}$ & $-8.75 \mathrm{e}-05^{* * *}$ \\
\hline & $(3.03 \mathrm{e}-06)$ & $(1.40 \mathrm{e}-06)$ \\
\hline \multirow[t]{2}{*}{ Andalusia } & $-7.12 \mathrm{e}-05 * * *$ & $-6.46 \mathrm{e}-05^{* * *}$ \\
\hline & $(7.47 \mathrm{e}-06)$ & $(4.86 \mathrm{e}-06)$ \\
\hline \multirow[t]{2}{*}{ Canary Islands } & $-2.49 \mathrm{e}-05^{* * *}$ & $-4.34 \mathrm{e}-05^{* * *}$ \\
\hline & $(3.04 \mathrm{e}-06)$ & $(1.71 \mathrm{e}-06)$ \\
\hline \multirow[t]{2}{*}{ Catalonia } & $-2.22 \mathrm{e}-05^{* * *}$ & $-2.25 \mathrm{e}-05^{* * *}$ \\
\hline & $(5.51 \mathrm{e}-06)$ & $(2.98 \mathrm{e}-06)$ \\
\hline \multirow[t]{2}{*}{ Valencia } & $-6.02 \mathrm{e}-05^{* * *}$ & $-6.45 \mathrm{e}-05^{* * *}$ \\
\hline & $(1.84 \mathrm{e}-06)$ & $(6.39 \mathrm{e}-07)$ \\
\hline \multirow[t]{2}{*}{ Country Basque } & $-3.57 \mathrm{e}-05^{* * *}$ & $-2.40 \mathrm{e}-05^{* * *}$ \\
\hline & $(1.47 e-06)$ & $(1.14 \mathrm{e}-06)$ \\
\hline \multirow[t]{2}{*}{ Extremadura } & $-2.10 \mathrm{e}-05^{* * *}$ & $-4.23 \mathrm{e}-05^{* * *}$ \\
\hline & $(4.70 \mathrm{e}-06)$ & $(4.54 \mathrm{e}-06)$ \\
\hline \multirow[t]{2}{*}{ Galicia } & $8.37 \mathrm{e}-05 * * *$ & $1.52 \mathrm{e}-05^{* * *}$ \\
\hline & $(1.77 \mathrm{e}-06)$ & $(3.94 \mathrm{e}-06)$ \\
\hline \multirow[t]{2}{*}{ Aragon } & $4.63 \mathrm{e}-05^{* * *}$ & $-3.83 e-05^{* * *}$ \\
\hline & $(7.18 \mathrm{e}-06)$ & $(6.01 \mathrm{e}-06)$ \\
\hline \multirow[t]{2}{*}{ Asturias } & $-5.27 \mathrm{e}-05^{* * *}$ & $-2.32 \mathrm{e}-05^{* * *}$ \\
\hline & $(3.72 \mathrm{e}-06)$ & $(2.26 \mathrm{e}-06)$ \\
\hline \multirow[t]{2}{*}{ Balearic Islands } & $-8.64 \mathrm{e}-05^{* * *}$ & $-0.000105 * * *$ \\
\hline & $(9.66 \mathrm{e}-06)$ & $(8.36 \mathrm{e}-06)$ \\
\hline \multirow[t]{2}{*}{ Cantabria } & $1.34 \mathrm{e}-05$ & $-3.50 \mathrm{e}-05^{* * *}$ \\
\hline & $(9.56 \mathrm{e}-06)$ & $(6.15 \mathrm{e}-06)$ \\
\hline \multirow[t]{2}{*}{ Castila la Mancha } & $-2.59 \mathrm{e}-05^{* * *}$ & $-6.00 \mathrm{e}-05^{* * *}$ \\
\hline & $(3.94 \mathrm{e}-06)$ & $(2.57 \mathrm{e}-06)$ \\
\hline \multirow[t]{2}{*}{ La Rioja } & $-2.90 \mathrm{e}-05^{* * *}$ & $-2.99 \mathrm{e}-05^{* * *}$ \\
\hline & $(8.28 \mathrm{e}-06)$ & $(6.45 \mathrm{e}-06)$ \\
\hline
\end{tabular}




\begin{tabular}{|c|c|c|}
\hline \multirow{2}{*}{ Variables } & \multicolumn{2}{|c|}{ Start-up entrepreneurs } \\
\hline & Model (1) & Model (2) \\
\hline \multirow[t]{2}{*}{ Murcia } & $-3.66 \mathrm{e}-05^{* * *}$ & $-5.26 \mathrm{e}-05^{* * * *}$ \\
\hline & $(8.29 \mathrm{e}-06)$ & $(5.29 \mathrm{e}-06)$ \\
\hline \multirow[t]{2}{*}{ Ceuta } & $-3.41 \mathrm{e}-05^{* *}$ & $-6.63 e-05 * * *$ \\
\hline & $(1.38 \mathrm{e}-05)$ & $(8.87 \mathrm{e}-06)$ \\
\hline \multirow[t]{2}{*}{ Melilla } & $-4.17 \mathrm{e}-05^{* * *}$ & $-8.70 \mathrm{e}-06$ \\
\hline & $(1.19 \mathrm{e}-05)$ & $(7.59 \mathrm{e}-06)$ \\
\hline \multicolumn{3}{|c|}{ Cohort 18 - 28 (Ref.) } \\
\hline \multirow[t]{2}{*}{ Cohort 29 - 38} & $0.0132 * * *$ & $0.00781 * * *$ \\
\hline & $(0.000439)$ & $(0.000152)$ \\
\hline \multirow[t]{2}{*}{ Cohort $39-48$} & $0.0284 * * *$ & $0.0279 * * *$ \\
\hline & $(0.000478)$ & $(0.000552)$ \\
\hline \multirow[t]{2}{*}{ Cohort $49-58$} & $0.0356^{* * *}$ & $0.0393 * * *$ \\
\hline & $(0.000680)$ & $(0.00102)$ \\
\hline \multirow[t]{2}{*}{ Cohort 59 -64 } & $0.0344 * * *$ & $0.0411 * * *$ \\
\hline & $(0.000648)$ & $(0.00139)$ \\
\hline \multicolumn{3}{|l|}{2006 (Ref.) } \\
\hline \multirow[t]{2}{*}{2007} & $0.00277 * * *$ & $0.000899 * * *$ \\
\hline & $(0.000101)$ & $(0.000176)$ \\
\hline \multirow[t]{2}{*}{2008} & $0.00122 * * *$ & $0.000557^{* * *}$ \\
\hline & $(5.17 \mathrm{e}-05)$ & $(4.09 \mathrm{e}-05)$ \\
\hline \multirow[t]{2}{*}{2009} & $-0.0273 * * *$ & $-0.0250 * * *$ \\
\hline & $(0.000106)$ & $(0.000182)$ \\
\hline \multirow[t]{2}{*}{ Constant } & $-0.106^{* * *}$ & $-0.131 * * *$ \\
\hline & $(0.00257)$ & $(0.00367)$ \\
\hline Observations & 114,866 & 114,866 \\
\hline R-squared & 0.986 & 0.992 \\
\hline
\end{tabular}

Note. Robust standard errors clustered by region and corrected by heteroscedasticity in parentheses.

$* * * \mathrm{p}<.01, * * \mathrm{p}<.05, * \mathrm{p}<.10$.

Model 1 shows that being a male and having more than 12 years of education is statistically significant for start-up entrepreneurs. Model 2 shows that personally knowing other entrepreneurs and having access to business angel investors have a positive effect upon start-up entrepreneurs. Therefore, $H 1$ and $H 2$ found support.

Furthermore, Table 3 contains the parameter estimates for cohorts, autonomous communities ${ }^{1}$, and year surveys. The cohort dummies capture fixed effects stemming from both observable and unobservable sources. Thereby, all cohorts' results are significant, but there are differences in the estimated coefficients. For instance, for start-up entrepreneurs, it is noteworthy that estimated coefficients are bigger for individuals in the cohorts aged 49-58 and 59-64 rather than for those individuals belonging to the two first cohorts. This suggests that individuals in the cohorts with ages ranging from 49 to 58 years do better compared to the younger individuals used in the sample for Model 2. Estimated coefficients for regional dummies are statistically significant with a negative relationship to start-up entrepreneurs, excepting Galicia (see Model 2). This suggests that there are differences at the regional level regarding the impact of informal networks upon start-up entrepreneurs.

Finally, year dummy coefficients show that 2007 and 2008 are statistically significant compared to 2006 for start-up entrepreneurs while 2009 relates negatively although it is significant (see Model 2). This suggests that 2009 could have included bad conditions for entrepreneurs in Spain. This result makes sense since in 2009 the financial crisis in Spain could have constrained entrepreneurial activities. 


\section{Discussion and Conclusion}

Although a Spanish sample is the basis for the findings of this article, they offer interesting insights concerning the influence of informal networks, personally knowing other entrepreneurs, and having access to business angel investors upon start-up for entrepreneurs in Spain. One interesting contribution of this paper is to show that personally knowing other entrepreneurs positively influences start-up entrepreneurs. It suggests that the reliance on networks is not constrained to start-up entrepreneurs but entrepreneurs continue to rely on networks to get information and resolve problems (Hoang \& Antoncic, 2003). Researchers can obtain these resources from individuals who are not entrepreneurs but also from entrepreneurs.

This study focused on the relationships between entrepreneurs who personally know other entrepreneurs. One contribution from this paper is to show that informal networks, such as knowing other entrepreneurs, are relevant for start-up entrepreneurs. This relationship involves a link among entrepreneurs, for instance there are associations of entrepreneurs where members discuss businesses. In this kind of network, members share information, such as new opportunities for investment, financial support, and other knowledge. Despite this result, it is known that relationships among businesses (entrepreneurs) are multiplex; it means that this kind of relationship also involves friendship, information, and business exchange (Human \& Provan, 1996).

On the other hand, it is know that informal investors play a role in entrepreneurship (Heukamp et al., 2006). These results showed that having access to business angel investors is significant for start-up entrepreneurs. This result is consistent with previous studies (Moen et al., 2008; Reitan \& Sorheim, 2000). Thus, this evidence suggests that start-up entrepreneurs used this kind of financing for their entrepreneurial activities in Spain.

\section{Implications}

This study has focused on the impact of two kinds of informal networks upon start-up entrepreneurs in Spain. First, networks from personally networking with other entrepreneurs showed significant results for start-up entrepreneurs in Spain. This suggests that networking activities are relevant and determinant in entrepreneurial activities. As was mentioned before, within a network of start-up entrepreneurs intangible resources exist that the members of such a network can leverage. In addition, this result brings some implications for policy-makers. One recommendation is that entrepreneurs should support public events because this could cause the interaction among entrepreneurs. For example, if entrepreneurs exist in a network of entrepreneurs, the internal resources from such networks could benefit other entrepreneurs. This is beneficial for regional development because strong networks among entrepreneurs also could create trust, and this could foster the business angel investment in the early stages of entrepreneurship. This could lead to positive effects for all the levels in the government, at the local and regional administrations and at national level.

\section{Endnote}

1 Autonomous communities refer to the geographical and political divisions in Spain.

\section{References}

Aldrich, H., \& Zimmer, C. (1986). Entrepreneurship through social networks. In D. L. Sexton and R. Smilor (Eds.), The Art and Science of Entrepreneurship. Cambridge, MA: Ballinger.

Arenius, P., \& Clercq, D. D. (2005). A network-based approach on opportunity recognition. Small Business Economics, 24(3), 249-265.

dx.doi.org/10.1007/s11187-005-1988-6

Arent, G. (1995). Networks and entrepreneurship - An analysis of social relations, occupational background, and use of contacts during the establishment process. Scandinavian Journal of Management, 11(1), 1-24. dx.doi. org/10.1016/0956-5221(94)00026-E

Baltagi, B. (2005). Econometric Analysis of Panel Data (3rd ed.). Chichester; Hoboken, NJ: John Wiley \& Sons.

Bernard, J., Bolduc, D., \& Yameogo, N. (2011). A pseudo-panel data model of household electricity demand. Resource and Energy Economics, 33(1), 315-325. dx.doi.org/10.1016/j.reseneeco.2010.07.002

Birley, S. (1985). The role of networks in the entrepreneurial process. Journal of Business Venturing, 1(1), 107-117. dx.doi. org/10.1016/0883-9026(85)90010-2 
Black, D., Tseng, Y., \& Wilkins, R. (2010). The decline in male employment in Australia: A cohort analysis. Australian Economic Papers, 49(3), 180-199. dx.doi.org/10.1111/j.1467-8454.2010.00395.x

Bosma, N., Mirjam, van P., \& Thurik, R. (2004). The value of human and social capital investments for the business performance of startups. Small Business Economics, 23(3), 227-236. dx.doi.org/0000032032.21192.72

Bourdieu, P. (1983). Forms of capital. In J. Richardson (Ed.), Handbook of Theory and Research for the Sociology of Education (pp. 241-258). New York, NY: Greenwood Press.

Brander, J. A., Amit, R., \& Antweiler, W. (2002). Venture-capital syndication: Improved venture selection vs. the valueAdded hypothesis. Journal of Economics \& Management Strategy, 11(3), 423-452. dx.doi.org/10.1111/j.1430-9134.2002. 00423.x

Coleman, J. S. (1988). Social capital in the creation of human capital. American Journal of Sociology, 94, 95-120.

Dargay, J. (2007). The effect of prices and income on car travel in the UK. Transportation Research Part A, 41, 949-960.

dx.doi.org/10.1016/j.tra.2007.05.005

Davidsson, P., \& Honig, B. (2003). The role of social and human capital among nascent entrepreneurs. Journal of Business Venturing, 18(3), 301-331.

dx.doi.org/10.1016/S0883-9026(02)00097-6

De Clercq, D., \& Arenius, P. (2006). The role of knowledge in business start-up activity. International Small Business Journal, 24(4), 339-358. dx.doi.org/10.1177/0266242606065507

Deaton, A. (1985). Panel data from time series of cross-sections. Journal of Econometrics, 30(1-2), 109-126. dx.doi. org/10.1016/0304-4076(85)90134-4

Falck, O., Heblich, S., \& Luedemann, E. (2012). Identity and entrepreneurship: Do school peers shape entrepreneurial intentions? Small Business Economics, 39(1), 39-59. dx.doi.org/10.1007/s11187-010-9292-5

Freear, J., Sohl, J. E., \& Wetzel Jr., W. E. (1994). Angels and non-angels: Are there differences? Journal of Business Venturing, 9(2), 109-123. dx.doi.org/10.1016/0883-9026(94)90004-3

Fuller-Love, N. (2009). Formal and informal networks in small businesses in the media industry. International Entrepreneurship and Management Journal, 5(3), 271-284. dx.doi.org/10.1007/s11365-008-0102-3

Greve, A., \& Salaff, J. W. (2003). Social networks and entrepreneurship. Entrepreneurship Theory and Practice, 28(1), 1-22. dx.doi.org/10.1111/1540-8520.00029

Heshmati, A., \& Kumbhakar, S. C. (1997). Estimation of technical efficiency in Swedish crop farms: A pseudo-panel data approach. Journal of Agricultural Economics, 48(1-3), 22-37. dx.doi.org/10.1111/j.1477-9552.1997.tb01128.x

Heukamp, F., Liechtenstein, H., \& Wakeling, N. (2006). Do Business Angels alter the risk-return equation in early stage investments? IESE Business School, University of Navarra, Working Paper 655.

Hoang, H., \& Antoncic, B. (2003). Network-based research in entrepreneurship: A critical review. Journal of Business Venturing, 18(2), 165-187. dx.doi.org/10.1016/S0883-9026(02)00081-2

Human, S., \& Provan, K. (1996). External resource exchange and perceptions of competitiveness within organizational networks: an organizational learning perspective. In Reynolds et al. (Eds.), Frontiers of Entrepreneurship Research (pp. 240-252). Wellesley, MA: Babson College.

Johannisson, B. (1988). Business formation: A network approach. Scandinavian Journal of Management, 31(3/4). dx.doi. org/10.1016/0956-5221(88)90002-4

Köllinger, P., \& Minniti, M. (2006). Not for lack of trying: American entrepreneurship in black and white. Small Business Economics, 27(1), 59.

dx.doi.org/10.1007/s11187-006-0019-6

Klyver, K., Hindle, K., \& Meyer, D. (2008). Influence of social network structure on entrepreneurship participation - A study of 20 national cultures. International Entrepreneurship and Management Journal, 4, 331-347. dx.doi.org/10.1007/s11365-007-0053-0

Lafuente, E., Vaillant, Y., \& Rialp, J. (2007). Regional differences in the influence of role models: Comparing the entrepreneurial process of rural Catalonia. Regional Studies, 41(6), 779. dx.doi.org/10.1080/00343400601120247

Landström, H. (1995). A pilot study on the investment decision-making behavior of informal investors in Sweden. Journal of Small Business Management, 33(3), 67.

Mason, C. M. (2007). Informal sources of venture finance. In S. Parker (Ed.), The Life Cycle of Entrepreneurial Ventures (Vol. 3, pp. 259-299). Boston, MA: Springer U.S.

Mason, C. M., \& Harrison, R. T. (1995). Closing the regional equity capital gap: The role of informal venture capital. Small Business Economics, 7, 153-172. dx.doi.org/10.1007/BF01108688

Mathews, C. H., \& Moser, S. B. (1995). Family background and gender: implications for interest in small firm ownership. Entrepreneurship \& Regional Development, 7, 365-378.

Maula, M., Autio, E., \& Arenius, P. (2005). What drives micro-angel investments? Small Business Economics, $25(5), 459$. dx.doi.org/10.1007/s11187-004-2278-4 
Maxwell, A. L., Jeffrey, S. A., \& Lévesque, M. (2011). Business angel early stage decision making. Journal of Business Venturing, 26(2), 212-225. dx.doi.org/10.1016/j.jbusvent.2009.09.002

Menzies, T. V., Diochon, M., Gasse, Y., \& Elgie, S. (2006). A longitudinal study of the characteristics, business creation process and outcome differences of Canadian female vs. male nascent entrepreneurs. The International Entrepreneurship and Management Journal, 2, 441-453. dx.doi.org/10.1007/s11365-006-0013-0

Moen, Ø., Sørheim, R., \& Erikson, T. (2008). Born global firms and informal investors: examining investor characteristics. Journal of Small Business Management, 46(4), 536-549. dx.doi.org/10.1111/j.1540-627X.2008.00255.x

Nakhaie, R., Lin, X., \& Guan, J. (2009). Social capital and the myth of minority self-employment: Evidence from Canada. Journal of Ethnic and Migration Studies, 35(4), 625-644. dx.doi.org/10.1080/13691830902765244

OECD. (2011). Angel investment: Definitions, data and processes» in Financing High-Growth Firms: The Role of Angel Investors. OECD Publishing. Retrieved from dx.doi.org/10.1787/9789264118782-4-en

Parker, S. C. (2002). Do banks ration credit to new enterprises? And should governments intervene? Scottish Journal of Political Economy, 49(2), 162-195. dx.doi.org/10.1111/1467-9485.00227

Ramos-Rodríguez, R., Medina-Garrido, J., \& Ruiz-Navarro, J. (2012). Determinants of hotels and restaurants entrepreneurship: A study using GEM data. International Journal of Hospitality Management, 31(2), 579-587.

dx.doi.org/10.1016/j.ijhm.2011.08.003

Ramos-Rodríguez, A., Medina-Garrido, J., Lorenzo-Gómez, J., \& Ruiz-Navarro, J. (2010). What you know or who you know? The role of intellectual and social capital in opportunity recognition. International Small Business Journal, 28(6), 566-582. dx.doi.org/10.1177/0266242610369753

Reitan, B., \& Sorheim, R. (2000). The informal venture capital market in Norway? Investor characteristics, behaviour and investment preferences. Venture Capital, 2(2), 129-141. dx.doi.org/10.1080/136910600295747

Reynolds, P., Bosma, N., Autio, E., Hunt, S., De Bono, N., Servais, I., \& Chin, N. (2005). Global Entrepreneurship Monitor: Data collection design and implementation 1998-2003. Small Business Economics, 24(3), 205-231. dx.doi. org/10.1007/s11187-005-1980-1

Roper, S., \& Scott, J. M. (2009). Perceived financial barriers and the start-up decision an econometric analysis of gender differences using GEM data. International Small Business Journal, 27(2), 149-171. dx.doi.org/10.1177/0266242608100488

Sengupta, A. (2011). Network strategy and access to business finance. Journal of Entrepreneurship, 20(1), 103-126. dx.doi.org/10.1177/097135571002000105

Sohl, J. (2007). The Organization of the informal venture capital market. In H. Lanström (Ed.), Handbook of Research on Venture Capital (pp. 347-370). Cheltenham, United Kingdom: Edward Elgar.

Sprietsma, M. (2012). Computers as pedagogical tools in Brazil: a pseudo-panel analysis. Education Economics, 20(1), 19-32.

dx.doi.org/10.1080/09645290903546496

Thompson, P., Jones-Evans, D., \& Kwong, C. (2009). Women and home-based entrepreneurship evidence from the United Kingdom. International Small Business Journal, 27(2), 227-239. dx.doi.org/10.1177/0266242608100492

Warunsiri, S., \& McNown, R. (2010). The returns to education in Thailand: A pseudo-panel approach. World Development, $38(11), 1616-1625$.

dx.doi.org/10.1016/j.worlddev.2010.03.002

Zali, M. R., Schøtt, T., Kordnaeij, A., \& Najafian, M. (2012). Entrepreneurs' networks affecting innovation: Firms in Iran and Denmark. African Journal of Business Management, 6(17). dx.doi.org/10.5897/AJBM11.1795

\section{Author Note}

Rocío Aliaga-Isla, Business Economics Department, Autonomous University of Barcelona, Edificio B, Campus de la UAB, 08193 Cerdañola del Vallés, Barcelona, Spain.

Correspondence concerning this article should be addressed to Rocío Aliaga-Isla, Email: rociodelpilar.aliaga@ecampus.uab.cat 


\section{Appendix}

Table A1

Review of the Usage of Cross-sectional Data in Academic Papers

\begin{tabular}{|c|c|c|c|c|c|}
\hline Author & Journal & Data & Country & $\begin{array}{l}\text { Usage of year } \\
\text { survey }\end{array}$ & Technique \\
\hline Ramos-Rodriguez et al. (2010) & ISBJ & 2007 & Spain & Single year & $\begin{array}{l}\text { Logistic } \\
\text { regression }\end{array}$ \\
\hline Ramos-Rodriguez et al. (2012) & IJHM & 2008 & Spain & Single year & $\begin{array}{l}\text { Logistic } \\
\text { regression }\end{array}$ \\
\hline Roper and Scott (2009) & ISBJ & 2004 & The United Kingdom & Single year & Probit model \\
\hline Arenius and De Clecq (2005) & SBE & 2005 & Belgium and Finland & Single year & $\begin{array}{l}\text { Logistic } \\
\text { regression }\end{array}$ \\
\hline Thomson et al. (2009) & ISBJ & $2005-2006$ & The United Kingdom & Several years & Logit regression \\
\hline Zali et al. (2012) & AJBM & 2008,2009 and 2010 & Iran and Demark & Several years & $\begin{array}{l}\text { Multiple } \\
\text { regression }\end{array}$ \\
\hline
\end{tabular}

